\title{
The Use of E-Resources and Innovative Technology in Transforming Traditional Teaching in Chemistry and its Impact on Learning Chemistry
}

\author{
https://doi.org/10.3991/ijim.v12i7.9666 \\ Wong Yau Hsiung ( $\left.{ }^{\square}\right)$ \\ Taylor's University Lakeside Campus, Subang Jaya, Malaysia \\ yauhsiung.wong@taylors.edu.my
}

\begin{abstract}
Chemistry is often perceived as being a dry and boring science subject, probably because of traditional teaching method, static textbook, lack of interactivity and difficulty in visualization of the abstract chemical concepts. Elearning resources (e-resources) and the utilization of technology have become one of the major trends in education, replacing the conventional textbook and traditional talk and chalk teaching method. A study was undertaken to assess students' perceptions of the impact of the e-resources and technology on various aspects of their learning. Data were collected through a questionnaire involving 28 undergraduates, who were taking first-year Chemistry course in Taylor's University, Malaysia. A Moodle e-Learning platform was made available to the students, where the students can assess e-resources anytime and anywhere. Innovative technologies such as mobile clicker, simulation and augmented reality (AR) were integrated into classroom instruction. Most of the students found the e-resources provided useful and well prepared them for the assessments in the course. Their understanding and ability to answer questions had improved. They were motivated to study the subject because it was more interactive and engaging. Overall findings showed that these e-resources and innovative technologies gave positive impact on students learning in chemistry.
\end{abstract}

Keywords—Chemistry; Moodle: e-learning; clicker; augmented reality

\section{$1 \quad$ Introduction}

Chemistry is often perceived by many students as a challenging, dry and boring science subject. This is probably because of traditional teaching method, static textbook, lack of interactivity and difficulty in visualization of the abstract chemical concepts [1, 2]. Traditional chalk and talk teaching method make the learning process boring and does not actively engage the students. One of the solutions to this problem is to transform traditional teaching method and introduce new ways of teaching through internet and technology. This research study investigated the use of online resources and emerging technology in transforming traditional teaching of chemistry and its impact on the academic achievements of students. 


\section{Literature Review}

Blended learning approach combines face to face teaching sessions in classroom with self-regulated online learning activities [3, 4]. This approach has been found to be transformative and able to provide meaningful learning experiences [5]. Moreover, this approach has been shown to be more effective than traditional teaching method as this teaching approach engaged students and deepened their understanding [6, 7]. Nowadays most of the educational institutions are using blended learning by incorporating elearning and technology into conventional teaching $[8,9]$. Majority of institutions use Learning Management Systems (LMS) as a platform to promote and support student learning. It allows instructor to provide and manage online course by providing resources such as presentations, assignment, quizzes, video, and forums to students [10, 11]. Moodle is one of the most frequently adopted learning management system at educational institutions worldwide [12,13]. Mobile devices are being used profusely in the classrooms. Recently, many educational institutions have started to use mobile clickers in classroom because it has shown to create positive environment and improve academic performances $[14,15]$. They also engaged student and increased student motivation $[16,17,18]$.

Chemistry is often considered as a "visual" subject. Studies have showed that simulation motivated students to learn chemistry and increased quality learning outcome $[19,20]$. They help explains difficult concepts such as complex structure and chemical mechanisms more clearly than a printed textbook. Another emerging technology is augmented reality (AR). AR technology brings digital contents to life by integrating into the real world [21]. Students experiencing various difficulties with learning Chemistry, especially in the topic of molecular geometry due to reason of difficulty to imagine the spatial arrangement of atoms and molecules. Findings showed that AR was very effective in explaining the concepts of molecular geometry [22, 23, 24, 25]. On top of that, studies also showed that AR motivated students to learn chemistry and gave them positive learning experience $[26,27,28,29]$.

\section{$3 \quad$ Methodology}

In this study, the general chemistry I (CHEM 105) course was conducted via blended learning mode, a combination of both face-to-face (lecture) and online using TIMeS (Taylor's Integrated Moodle E-Learning System), a Moodle platform used in Taylor's University. In the teaching period, 3 hours per week was allocated for the face to face lecture. This course consisted of continuous assessment (70\%) and final examinations $(30 \%)$. This course was offered to first year undergraduate students in American Degree Program (ADP), School of Liberal Art and Sciences, Taylor's University.

A group of 28 students was used in this study. This group of students were coming from secondary school and they entered university in their first semester. This group of students had no prior experience using Moodle learning management system. Technical help and guidance on how to access TIMeS has been offered to them during their first week of orientation in university. With TIMeS, students can access online resources 
such as PowerPoint notes, mind map, video, animations, simulation and practice quizzes using TIMeS. In addition, several web-based simulations from external source were made available in TIMeS to support student learning. The chemistry simulations are provided by some websites such as PhET simulations (https://phet.colorado.edu). An AR mobile apps known as "Zappar" was introduced in this course to create interactive contents. "Zap codes" were created to be embeded into PowerPoint or printed materials, where students can use the camera to scan the code to get more digital contents.

Before the face to face lecture, the students were required to explore the online resources in TIMeS. Student were instructed to complete two online quizzes in TIMeS in the form of multiple choice questions for every topics covered, namely pre-lecture and post-lecture quiz. The multiple-choice questions were created using Pearson test generator "TestGen" and imported into TIMeS. Every question in the test bank library was labelled with difficulty level, topic or section covered and learning objective. Different questions with similar difficulty level were included in the pre-lecture and post-lecture quiz to effectively measure student improvement in answering questions. Student were required to self-assess themselves by completing a pre-lecture quiz in TIMeS. The online quizzes were open for 2 days and only one attempt was allowed, and students could choose where and when to complete the quiz. Once the quiz has started, there was a time limit of one hour prior to submission. Immediate feedback was given once the quiz was completed, indicating the overall score and which questions were answered correctly. Personalized verbal feedback was given in the face to face lecture as further explanation. Two mobile clickers, "Poll-Everywhere" and "Kahoot" were used as formative assessment during the face to face lecture to further reinforce their understanding. At the end of the week, students were required to complete a post-lecture quiz in TIMeS with the same setting as pre-lecture quiz. The results of pre-lecture and postlecture quiz were recorded in TIMeS and the learning analytics were extracted and analysed. Final grade from students were also recorded.

At the end of the semester, an online questionnaire consisting of 14 questions and statements were administered. Students were required to rate each statement as "strongly agree", "agree", "neutral", "disagree" or "strongly disagree". Students were allowed to comment on each statement after rating. The aim of the questionnaire is to collect student feedback on the online resources in TIMeS and learning technology used in this course and the impact on their learning.

\section{$4 \quad$ Results}

In the current study, 28 students were responded to the questionnaire. $53.6 \%$ of the participants were female and $46.4 \%$ were male. Majority of the students were majored in the field of engineering (39.3\%) and the remaining of the students were majored in business $(39.3 \%)$, liberal arts/communication/social science $(14.3 \%)$ and computer science $(7.1 \%)$. When asked about the frequency which they accessed the online resources, $28.6 \%$ of them said that they spent on an average of 2-4 hours per week, while $28.6 \%$ said an average of 4-6 hours per week. Interestingly, $10.7 \%$ of the students spent more than 10 hours per week and $7.1 \%$ for less than 2 hours per week. 


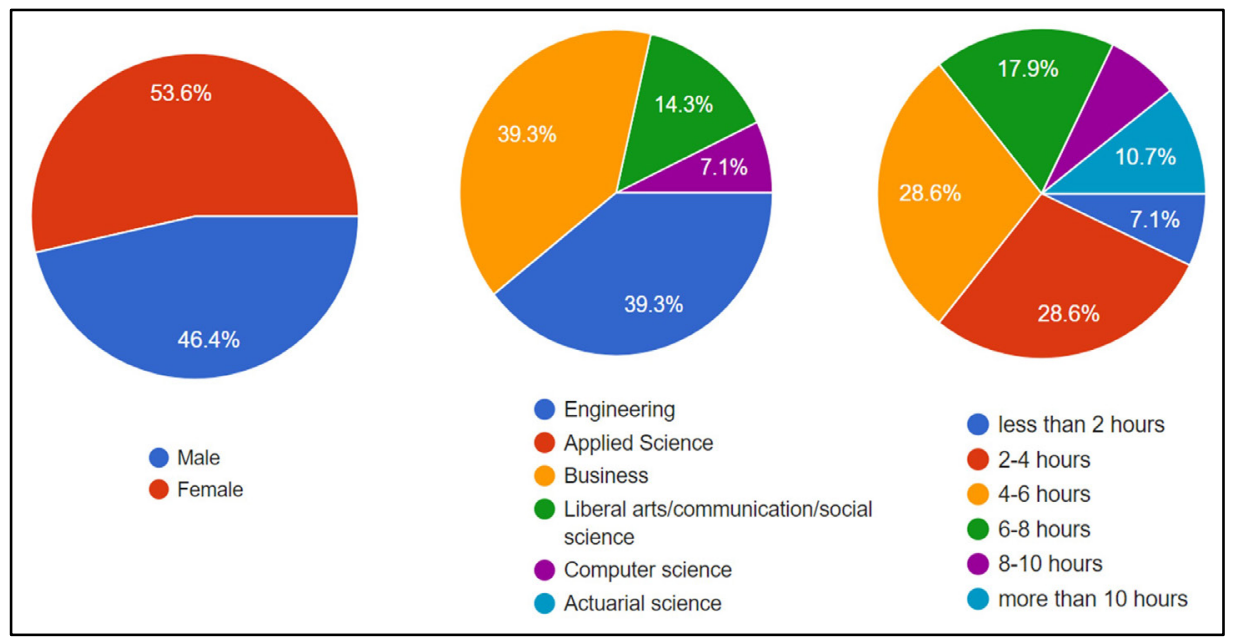

Fig. 1. Background information of students and average time spent in TIMeS in a week

As shown in figure 2, students obtained higher score in the post-lecture quiz when compared to pre-lecture quiz. Student's grade at the end of the semester was also recorded. As presented in figure 3, passing rate of $100 \%$ was observed with no students failed the course. A total of $47.37 \%$ of the student population scored with the grade of $\mathrm{A}+$ and $\mathrm{A}, 36.85 \%$ grade $\mathrm{B}$ and $\mathrm{B}-$ and $15.79 \%$ grade of $\mathrm{C}+$ and $\mathrm{C}$.

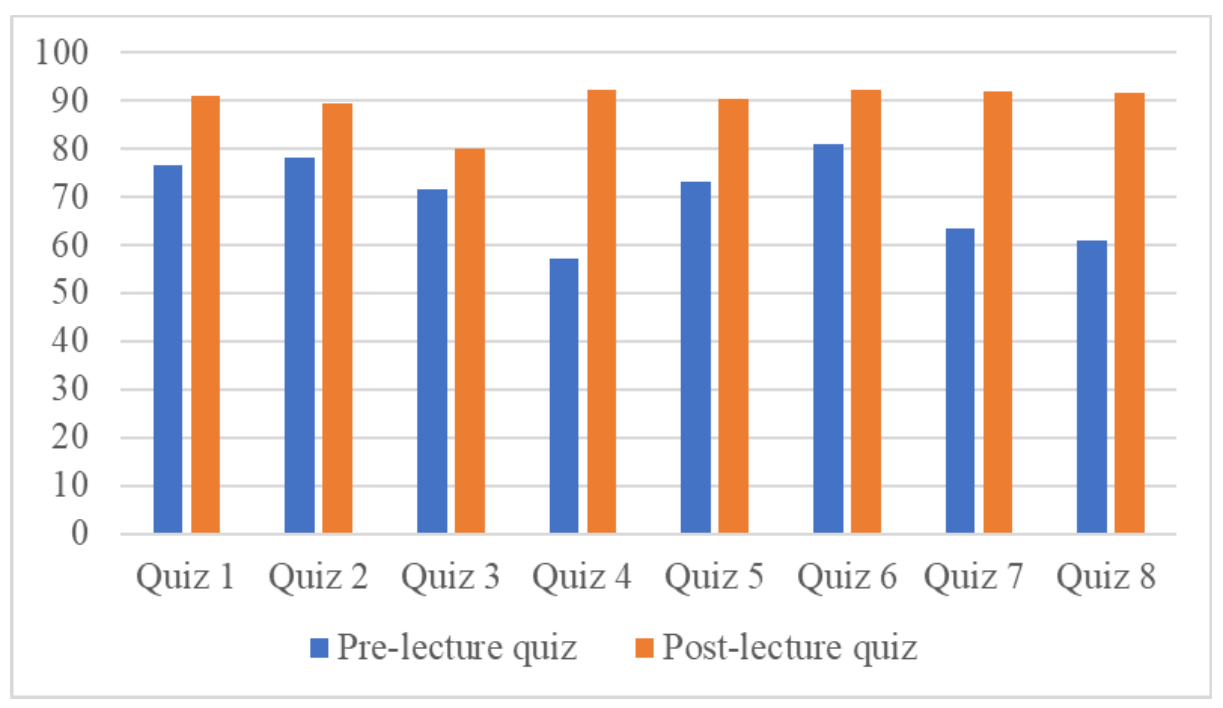

Fig. 2. Average scores for pre-lecture and post-lecture quiz. 


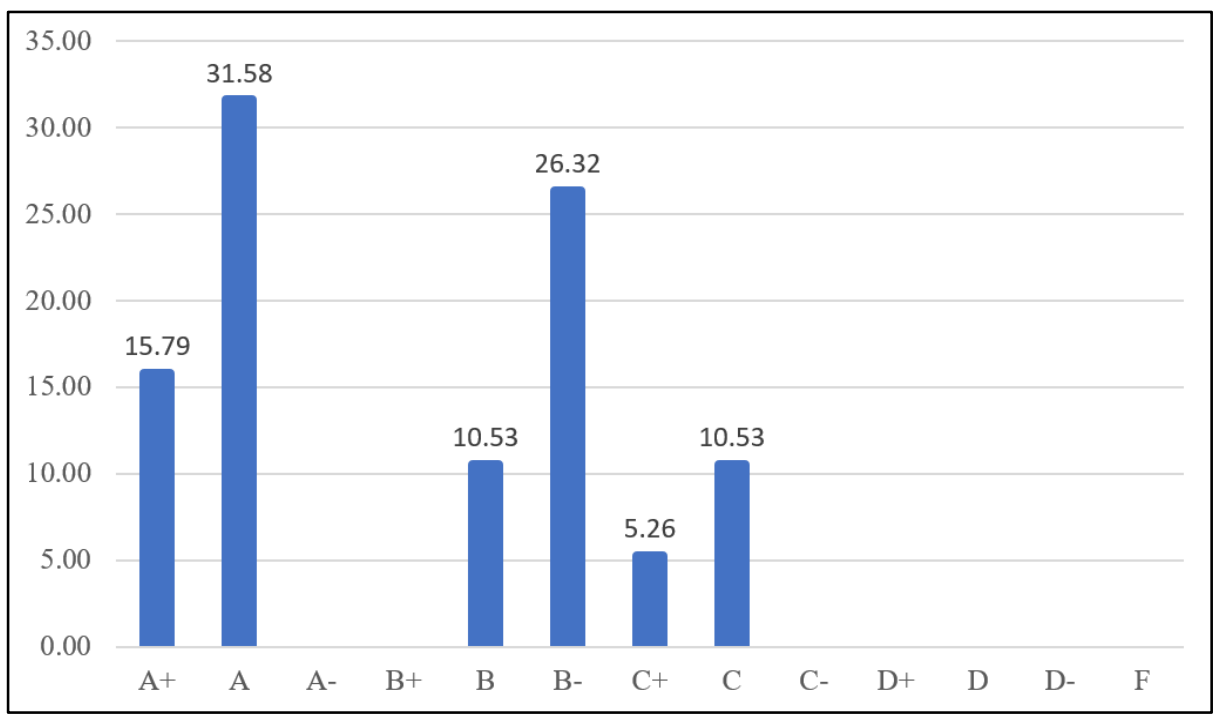

Fig. 3. Overall grade obtained by students at the end of the semester.

Results from the online questionnaire were analyzed and summarized in figure 4 and figure 5. In the questionnaire, students were asked to give their feedback on the impact of various online resources in TIMeS and how greatly they helped them in learning. Based on the results presented in Figure 4, power point notes/mind map $(53.57 \%)$, online quiz (64.29\%) and uploaded exercise with solution $(57.14 \%)$ were identified as the top three resources that greatly helped them in learning.

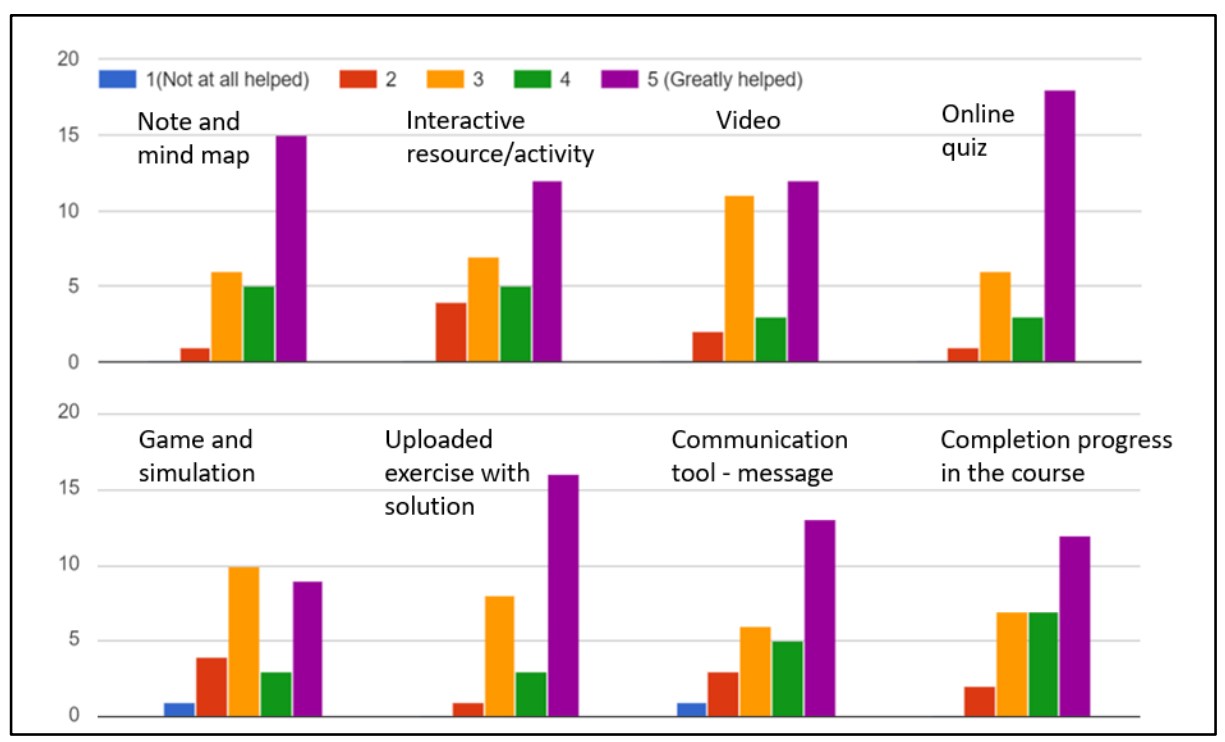

Fig. 4. Online resources in TIMeS 


\section{Overall the quality of online resources in TIMeS}

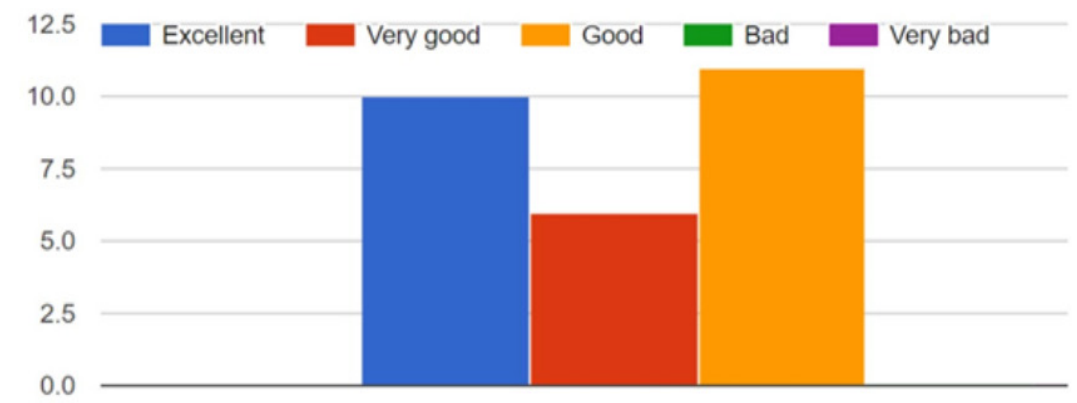

TIMeS helps me to prepare well for class sessions

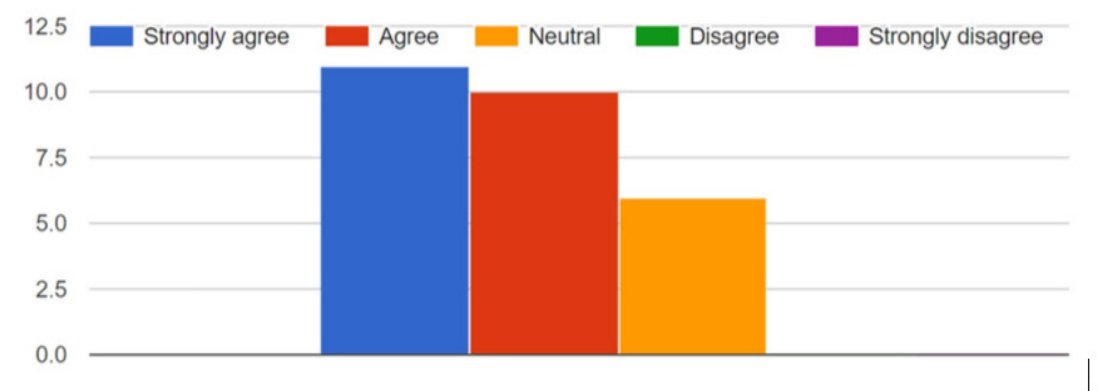

The online activities in TIMeS such as practice quizzes gave me feedback on my performances

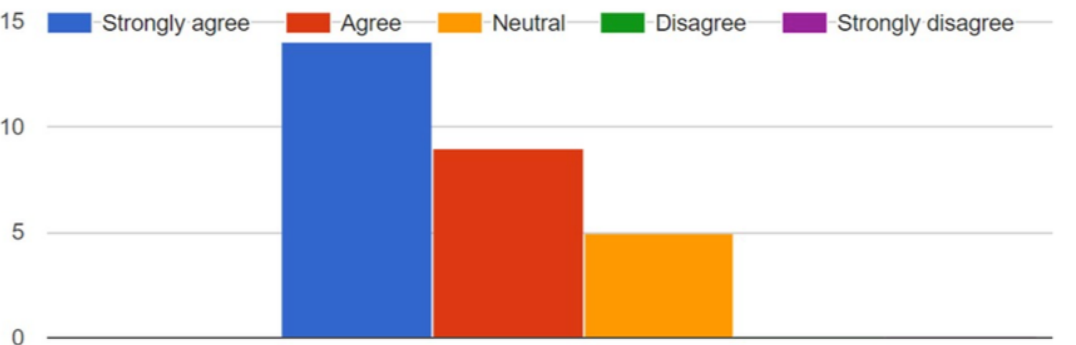


The online resources in TIMeS helped me to identify problem areas that I needed to study

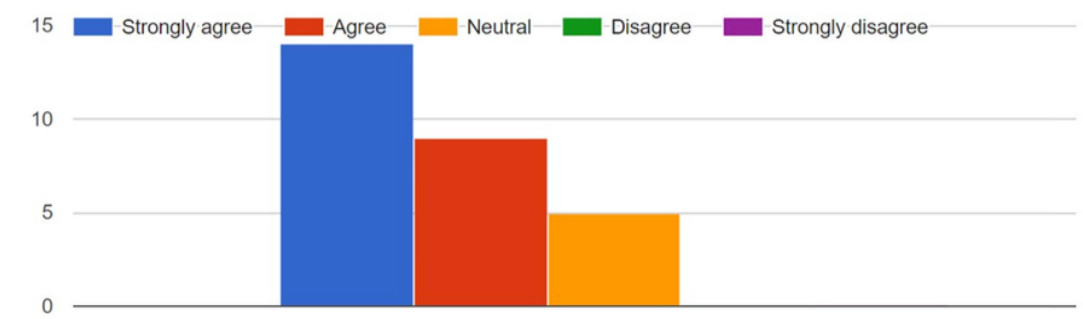

The online resources and technology used in the course made my learning engaged and enjoyed

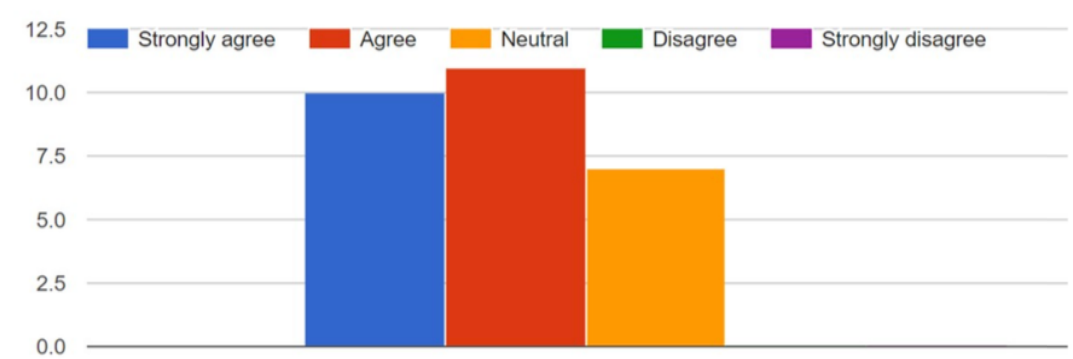

I gained a better understanding of chemical concepts after this course

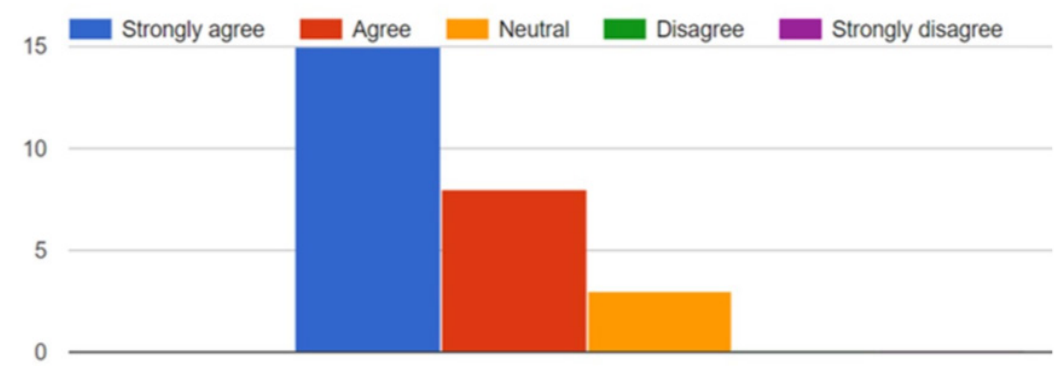

Fig. 5. Response of students on the statements in the questionnaire 
Student's response and comments on the statements in the questionnaire were captured and summarized in figure 5 . Overall, $35.71 \%$ of students rated the online resources as "excellent". $75 \%$ of the students said that online resources prepared them well for class sessions. Some students commented: "I go through the slides myself before my lecturer so that I can have a better understanding of what I am going to learn that day", "Class lessons are based on slides uploaded in TIMeS which I can read ahead", "The slides provided really helps". A total of $82.14 \%$ of the students agreed that online quizzes in TIMeS gave them valuable feedback. Some students said, "It's easy to find out where I made the mistake", "It is useful for me to study and know my weakness", "I learn from my mistakes and parts of where I wasn't so sure of". 82.14 \% of them also agreed that the online resources were helpful in identifying their problem areas. Indeed, some students did say that "Really helpful to identify my problems".75 $\%$ of them were engaged and enjoyed with the online resources and technology used. Some of the comments: "It's interesting to play games and videos while learning", "I love the competitive nature of Kahoot!", "not boring and old-fashioned", "Kahoot is very enjoying and fun". Lastly, $82.14 \%$ of them were agreed that they gained a better understanding of chemistry concepts after taking this course.

\section{Discussion}

The students who enrolled in this chemistry course did not have any prior experience in using learning management system. Results from this study revealed that students responded positively to the usage of Moodle as an enhancement to their face to face lectures. They liked the interactivity and rich contents of the TIMeS. However, some students were not satisfied with the occasional interruption and inaccessibility of TIMeS due to internet connectivity problems or server maintenance issues. Overall, results showed that the online contents in TIMeS did helped them in their study. Studies have found that students generally demonstrated positive effects on performance after experienced a well-designed online course enriched with resources [30].

In TIMeS, the student's activities were monitored by Moodle log. One of the useful features of Moodle is the completion progress bar. Results of the questionnaire showed that this feature had greatly helped them in their study. This feature can be used as a motivational and time-management tool for students, where students can visually check their progress through the course. This is important because it allows teacher to measure the engagement level of students in the course helps to identify students who may be at risk of failing the course.

In this study, students were required to access the online resources and complete a pre-lecture quiz in TIMeS before the face to face lecture begins. This exercise encouraged students to evaluate their own learning and understanding through online quizzes. Results from pre-lecture and post-lecture quiz showed that student's understanding and ability to answer questions had improved. The blended learning approach used in course aimed to promote active participation of students in both face to face lecture and online learning using Moodle. The active participation of students in the face to face lecture was possible with the use of mobile clickers, which were used a formative 
assessment. Questionnaires revealed that students preferred "Kahoot" than "Poll-Everywhere". Some said that they learned Chemistry better by playing "Kahoot". Overall, the use of mobile clickers in class have created a fun, interactive and engaging experience. Additionally, simulation and augmented reality had amplified the learning experiences in this course. Students enjoyed the exploration experience and said that it helped them in visualization of complex structure. It has transformed a dull and "dry" chemistry into a life and engaging experience.

\section{Conclusion}

Overall findings showed that students were satisfied with the online resources provided in this chemistry course. Together with the use of innovative technology in classroom such as mobile clicker and augmented reality, they gave positive impact on students learning.

\section{$7 \quad$ Limitations and Future Studies}

There were several challenges in this study. The students must have the necessary ICT skills to use the TIMeS and work independently online. The online resources need to be designed carefully so that they are meaningful and align with the learning objectives. Future direction would be to improve the interface of Moodle, to make it more acceptable to users.

\section{Acknowledgement}

This study was supported by e-learning grant from Taylor's University and FRGS grant from Ministry of Higher Education (MOHE), Malaysia.

\section{$9 \quad$ References}

[1] Sirhan, G. (2007). Learning difficulties in chemistry: An overview. Journal of Turkish science education, 4(2), 2.

[2] Berg, C. A. R. (2005). Factors related to observed attitude change toward learning chemistry among university students. Chemistry Education Research and Practice, 6(1), 1-18. https://doi.org/10.1039/B4RP90001D

[3] Graham, C. R. (2006). Blended learning systems. The handbook of blended learning, 3-21.

[4] Alonso, F., López, G., Manrique, D., \& Vi-es, J. M. (2005). An instructional model for webbased e-learning education with a blended learning process approach. British Journal of educational technology, 36(2), 217-235. https://doi.org/10.1111/j.1467-8535.2005.00454.x

[5] Garrison, D. R., \& Kanuka, H. (2004). Blended learning: Uncovering its transforma-tive potential in higher education. The internet and higher education, 7(2), 95-105. https://doi.org/10.1016/j.iheduc.2004.02.001 
[6] Williams, N. A., Bland, W., \& Christie, G. (2008). Improving student achievement and satisfaction by adopting a blended learning approach to inorganic chemistry. Chemis-try Education Research and Practice, 9(1), 43-50. https://doi.org/10.1039/B801290N

[7] Pereira, J. A., Pleguezuelos, E., Merí, A., Molina-Ros, A., Molina-Tomás, M. C., \& Masdeu, C. (2007). Effectiveness of using blended learning strategies for teaching and learning human anatomy. Medical education, 41(2), 189-195. https://doi.org/10.1111/j.13652929.2006.02672.x

[8] Gaebel, M., Kupriyanova, V., Morais, R., \& Colucci, E. (2014). E-Learning in Europe-an Higher Education Institutions: Results of a Mapping Survey Conducted in Octo-ber-December 2013. European University Association.

[9] Beatty, I. D., \& Gerace, W. J. (2009). Technology-enhanced formative assessment: A research-based pedagogy for teaching science with classroom response technology. Journal of Science Education and Technology, 18(2), 146-162. https://doi.org/10.1007/s10956-0089140-4

[10] Pi-a, A. A. (2012). An overview of learning management systems. Virtual Learning Environments: Concepts, methodologies, tools and applications, 33-51.

[11] Berggren, A., Burgos, D., Fontana, J. M., Hinkelman, D., Hung, V., Hursh, A., et al. (2005). Practical and Pedagogical Issues for Teacher Adoption of IMS Learning Design Standards in Moodle LMS. Journal of Interactive Media in Education, 1-24. https://doi.org/10.5334/ $\underline{2005-2}$

[12] Horvat, A., Dobrota, M., Krsmanovic, M., \& Cudanov, M. (2015). Student perception of Moodle learning management system: a satisfaction and significance analysis. In-teractive Learning Environments, 23(4), 515-527. https://doi.org/10.1080/10494820.2013.788033

[13] Ivanovic, M., Putnik, Z., Komlenov, Z., Welzer, T., Hölbl, M., \& Schweighofer, T. (2013). Usability and privacy aspects of Moodle: students' and teachers' perspective. Informatica, 37(3), 221.

[14] Vital, F. (2011). Creating a positive learning environment with the use of clickers in a high school chemistry classroom. Journal of chemical education, 89(4), 470-473. https://doi.org/10.1021/ed101160x

[15] Ma, S., Steger, D. G., Doolittle, P. E., \& Stewart, A. C. (2018). Improved Academic Performance and Student Perceptions of Learning Through Use of a Cell Phone-Based Personal Response System. Journal of Food Science Education, 17(1), 27-32. https://doi.org/10.1111/1541-4329.12131

[16] McClean, S., \& Crowe, W. (2017). Making room for interactivity: using the cloud-based audience response system Nearpod to enhance engagement in lectures. FEMS microbiology letters, 364(6). https://doi.org/10.1093/femsle/fnx052

[17] Lim, T. Y., Khor, C. Y., \& Oon, Y. B. (2017, July). Measuring User Engagement in Mobile Classroom Response System: A Case Study. In International Conference on Learning and Collaboration Technologies (pp. 375-388). Springer, Cham.

[18] Cain, J., Black, E. P., \& Rohr, J. (2009). An audience response system strategy to im-prove student motivation, attention, and feedback. American Journal of Pharmaceuti-cal Education, 73(2), 21. https://doi.org/10.5688/aj730221

[19] Figueiredo, M., Rafael, C., Neves, J., \& Vicente, H. (2017, June). Assessing the Role of Computer Simulation in Chemistry Learning. In International Conference in Method-ologies and intelligent Systems for Techhnology Enhanced Learning (pp. 47-56). Springer, Cham. https://doi.org/10.1007/978-3-319-60819-8_6

[20] Urhahne, D., Nick, S., \& Schanze, S. (2009). The effect of three-dimensional simula-tions on the understanding of chemical structures and their properties. Research in Science Education, 39(4), 495-513. https://doi.org/10.1007/s11165-008-9091-Z 
[21] Yuen, S. C. Y., Yaoyuneyong, G., \& Johnson, E. (2011). Augmented reality: An over-view and five directions for AR in education. Journal of Educational Technology De-velopment and Exchange (JETDE), 4(1), 11.

[22] Maier, P., Tönnis, M., \& Klinker, G. (2009, May). Augmented Reality for teaching spa-tial relations. In Conference of the International Journal of Arts \& Sciences, Toronto.

[23] Nú-ez, M., Quirós, R., Nú-ez, I., Carda, J. B., Camahort, E., \& Mauri, J. L. (2008, July). Collaborative augmented reality for inorganic chemistry education. In WSEAS Inter-national Conference. Proceedings. Mathematics and Computers in Science and Engi-neering (Vol. 5, pp. 271-277). WSEAS.

[24] Kaufmann, H. (2002, December). Construct3D: an augmented reality application for mathematics and geometry education. In Proceedings of the tenth ACM international conference on Multimedia (pp. 656-657). ACM. https://doi.org/10.1145/641007.641140

[25] Chen, Y. C. (2006, June). A study of comparing the use of augmented reality and phys-ical models in chemistry education. In Proceedings of the 2006 ACM international conference on Virtual reality continuum and its applications (pp. 369-372). ACM.

[26] Cai, S., Wang, X., \& Chiang, F. K. (2014). A case study of Augmented Reality simula-tion system application in a chemistry course. Computers in Human Behavior, 37, 31-40. https://doi.org/10.1016/j.chb.2014.04.018

[27] Merchant, Z., Goetz, E. T., Keeney-Kennicutt, W., Kwok, O. M., Cifuentes, L., \& Davis, T. J. (2012). The learner characteristics, features of desktop 3D virtual reality envi-ronments, and college chemistry instruction: A structural equation modeling analysis. Computers \& Education, 59(2), 551-568. https://doi.org/10.1016/j.compedu.2012.02.004

[28] Dalgarno, B., Bishop, A. G., Adlong, W., \& Bedgood Jr, D. R. (2009). Effectiveness of a virtual laboratory as a preparatory resource for distance education chemistry stu-dents. Computers \& Education, 53(3), 853-865. https://doi.org/10.1016/i.compedu.2009.05.005

[29] Medina, E., Chen, Y. C., \& Weghorst, S. (2007, June). Understanding biochemistry with augmented reality. In EdMedia: World Conference on Educational Media and Technology (pp. 4235-4239). Association for the Advancement of Computing in Ed-ucation (AACE).

[30] Weaver, D., Spratt, C., \& Nair, C. S. (2008). Academic and student use of a learning management system: Implications for quality. Australasian journal of educational technology, 24(1). https://doi.org/10.14742/ajet.1228

\section{Author}

Wong Yau Hsiung is a senior lecturer from Department of Engineering and Applied Science, American Degree Transfer Program (ADP), School of Liberal Arts and Sciences, Taylor's University Lakeside Campus, Malaysia.

Article submitted 07 October 2018. Resubmitted 29 October 2018. Final acceptance 04 November 2018. Final version published as submitted by the authors. 